Tohoku J. exp. Med., 1978, 125, 59-69

\title{
The Significance of the Sweat Test in Chronic Pancreatitis
}

\author{
Makoto Hanawa, Takaaki Takebe, Susumu Takahashi, \\ Masaru Koizumi and Katsuhiro Endo
}

The Third Department of Internal Medicine, Tohoku University School of Medicine, Sendai 980

\begin{abstract}
Hanawa, M., Takebe, T., Takahash, S., Kolzumi, M. and Endo, K. The Significance of the Sweat Test in Chronic Pancreatitis. Tohoku J. exp. Med., 1978, 125 (1), 59-69 In order to study the disposition which is thought to be latent in chronic pancreatitis, we investigated the sweat chloride concentration of 95 normal subjects, 43 cases of chronic pancreatitis, 12 cases of cholelithiasis, 15 cases of peptic ulcers, 16 cases of hepatic diseases and 23 cases of diabetes mellitus with the sweat test, using the method of pilocarpine iontophoresis. We obtained the following results. (1) In normal subjects, the sweat chloride concentration was inclined to rise gradually with age from childhood to adulthood; the mean value of sweat chloride concentration was $30.0 \mathrm{mEq} / \mathrm{liter}$ in adults from 20 years old, and the upper limit was about $60 \mathrm{mEq} / \mathrm{liter}$. (2) The mean value of sweat chloride concentration was $60.0 \mathrm{mEq} /$ liter in chronic calcifying pancreatitis; this value was markedly higher than that of control subjects of the same age ( $p$ $<0.001$ ). (3) The mean value of sweat chloride concentration in cholelithiasis, peptic ulcer and hepatic diseases did not differ significantly from control subjects. The mean value of sweat chloride concentration in diabetes mellitus was significantly higher than that of control subjects $(p<0.01)$, but was significantly lower than that in chronic pancreatitis $(p<0.01)$. (4) It was supposed that some cases of chronic pancreatitis have a congenital disposition toward abnormal secretion of sweat glands and epithelium in the pancreatic duct, resembling cystic fibrosis, and this disposition leads easily to pancreatic disorders when the individual is exposed to various external factors. - sweat test; sweat chloride concentration; chronic pancreatitis; cystic fibrosis
\end{abstract}

Even now it is not adequately known why the parenchymal destruction and the increase of interstitial connective tissue of the pancreas progress gradually in chronic pancreatitis. But recently, it has been supposed that the disposition toward pancreatic disorders already exists when external factors, for example, alcohol or cholelithiasis, are added. Among the congenital factors are aminoaciduria (Gross et al. 1962), hyperlipidemia (Klatskin and Gordon 1952), hyperparathyroidism (Carey and Fitz Gerald 1968), $\alpha_{1}$-antitrypsin deficiency (Novis et al. 1975) and cystic fibrosis (Koch 1964; Sarles et al. 1965; Paul and Pamela 1976a, b, c).

Especially since the protein plugs in pancreatic ducts of cystic fibrosis are similar to the protein plugs in pancreatic ducts of chronic pancreatitis, it is thought Received for publication, September 26, 1977. 
that the congenital disorders in exocrine function of cystic fibrosis are connected with the pathogenesis of chronic pancreatitis. It is also known that cystic fibrosis is characterized by elevated sweat electrolytes. From this point of view, we investigated the sweat chloride concentration in chronic pancreatitis.

\section{Subjects ANd Methods}

Table 1 shows the controls and patients tested. They included 95 control subjects (43 men and 52 women, from 7 to 74 years old), 43 cases of chronic pancreatitis and 66 cases of various diseases which are thought to correlate with the outbreak of pancreatitis.

Out of 43 cases of chronic pancreatitis, 5 cases were diagnosed by histological investigation, 38 cases by the existence of calcification in the pancreatic ducts and 13 cases by both. The CCK-PZ secretin test was performed in 38 cases; 33 cases had severe or moderate abnormal exocrine pancreatic function, 2 cases had slight malfunction and 3 cases of calcification were normal. Exocrine pancreatic function was studied 12 out of the 66 cases of various diseases; all were normal except 1 case of a slight disturbance.

The sweat test was performed in accordance with Gibson and Cooke's pilocarpine iontophoresis method (Gibson and Cooke 1959). First, in the early morning when hungry, the forearm is washed with distilled water and adequately dried. Then, $4 \mathrm{ml}$ of $0.1 \%$

TABLE 1. Cases subjected to the investigation

\begin{tabular}{lr}
\multicolumn{1}{c}{ Cases } & Number \\
\hline Control & 95 \\
Chronic pancreatitis & 43 \\
Cholelithiasis & 12 \\
Gastric ulcer & 8 \\
Duodenal ulcer & 7 \\
Chronic hepatitis & 9 \\
Liver cirrhosis & 7 \\
Diabetes mellitus & 23 \\
$\quad$ Total & 204 \\
\hline
\end{tabular}

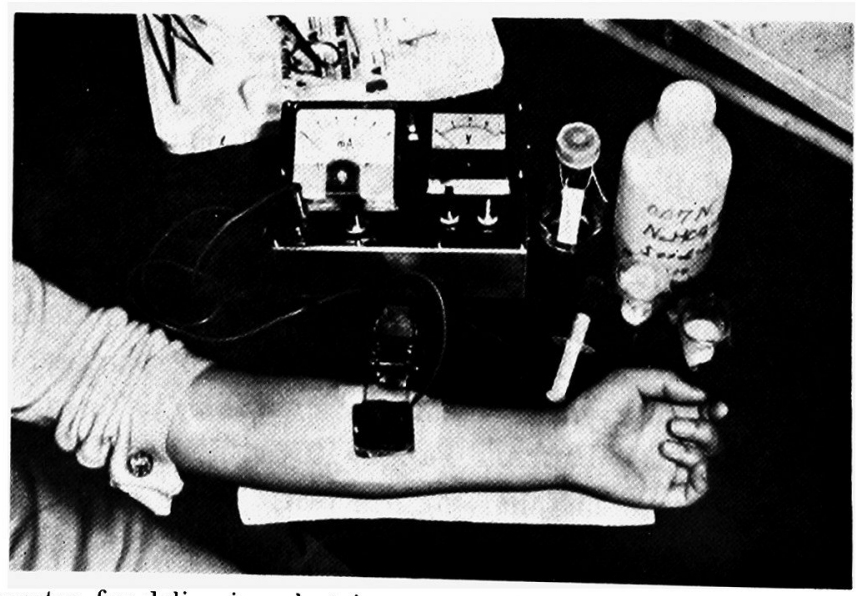
Fig. 1. Apparatus for delivering electric current; the electrodes and the collecting system
applied to a forearm. 
pilocarpine solution are poured on to 7 by $7 \mathrm{~cm}$ gauze squares placed on the flexor surface of the forearm. The positive electrode is applied to it and the gauze-covered negative one, on which a few milliliters of $0.07 \mathrm{~N}$ sodium bicarbonate solution are poured, is placed behind it on the extensor surface. Next, iontophoresis is continued with a current of 1 $\mathrm{mA}$ for $15 \mathrm{~min}$ (Fig. 1). After iontophoresis is complete, the electrodes and the gauze are removed and the skin is cleaned with distilled water and dried with gauze and a fan. A previously weighed gauze is placed on the flexor surface of the forearm that was iontophoresed. The area is covered with a parafilm, the edges of which are each carefully secured with four strips of adhesive tape. After a collection period of $30 \mathrm{~min}$, the gauze is removed and the gauze moist with sweat quickly returned to a weighed bottle and reweighed. Determination of the sweat chloride concentrations was performed by the method of Schales and Schales.

\section{Results}

The sweat chloride concentration when various pilocarpine concentrations were given

The sweat test was performed with $0.1 \%, 0.5 \%$, and $1.0 \%$ pilocarpine concentrations on 5 healthy controls. The concentration of pilocarpine was investigated once each day for each control, the order of the testing in the five controls being random. The conditions of the test were made as uniform as possible. It was found that when the concentrations of pilocarpine were $0.1 \%, 0.5 \%$ and $1.0 \%$, the mean values of the volume and the chloride concentration of sweat were $0.421 \mathrm{~g}, 25.0 \mathrm{mEq} / \mathrm{liter} ; 0.697 \mathrm{~g}, 26.4 \mathrm{mEq} / \mathrm{liter}$; and $0.626 \mathrm{~g}, 29.6 \mathrm{mEq} / \mathrm{liter}$, respectively. So, even if the concentrations of pilocarpine were altered, the volume and the chloride concentration of sweat did not change significantly (Table 2).

\section{The effect of eating on the sweat chloride concentration}

The sweat test was performed in 15 cases, mainly consisting of healthy controls, on the same day at 10 o'clock a.m. before eating and 5 o'clock p.m. after eating. It was found that if the sweat chloride concentration before eating was assumed to be $100 \%$, that after eating was $104 \pm 11.8 \%$ (mean \pm S.D.), while, if that after eating was $100 \%$, that before eating was $96.7 \pm 11.0 \%$. Therefore the change of sweat chloride concentration due to eating was thought to be about $10 \%$.

TABLE 2. Chloride concentration and weight of the sweat of controls in various pilocarpine concentrations

\begin{tabular}{|c|c|c|c|c|c|c|}
\hline \multirow[b]{2}{*}{ Controls } & \multicolumn{2}{|c|}{$0.1 \%$} & \multicolumn{2}{|c|}{$0.5 \%$} & \multicolumn{2}{|c|}{$1.0 \%$} \\
\hline & $\begin{array}{l}\text { Weight } \\
\text { (g) }\end{array}$ & $\begin{array}{c}\mathrm{Cl}^{-} \text {conc. } \\
\text { (mEq/liter) }\end{array}$ & $\begin{array}{c}\text { Weight } \\
\text { (g) }\end{array}$ & $\begin{array}{c}\mathrm{Cl}^{-} \text {conc. } \\
\text { (mEq/liter) }\end{array}$ & $\begin{array}{l}\text { Weight } \\
\text { (g) }\end{array}$ & $\begin{array}{c}\mathrm{Cl}^{-} \text {conc. } \\
(\mathrm{mEq} / \text { liter })\end{array}$ \\
\hline$A$ & 0.174 & 21.8 & 0.505 & 20.6 & 0.484 & 24.4 \\
\hline B & 0.620 & 34.8 & 0.784 & 38.5 & 0.615 & 43.9 \\
\hline $\mathrm{C}$ & 0.531 & 27.9 & 0.774 & 30.1 & 0.611 & 32.1 \\
\hline $\mathrm{D}$ & 0.416 & 23.6 & 0.685 & 24.8 & 0.627 & 28.4 \\
\hline $\mathrm{E}$ & 0.365 & 17.0 & 0.739 & 18.1 & 0.795 & 19.1 \\
\hline Mean & 0.421 & 25.0 & 0.697 & 26.4 & 0.626 & 29.6 \\
\hline S.D. & 0.152 & 5.91 & 0.102 & 7.28 & 0.099 & 8.36 \\
\hline
\end{tabular}


TABle 3. Sex and age distribution of control subjects

\begin{tabular}{crrr}
\hline Age & Male & Female & Total \\
\hline $0-9$ & 2 & 3 & 5 \\
$10-19$ & 1 & 8 & 9 \\
$20-29$ & 17 & 5 & 22 \\
$30-39$ & 12 & 9 & 21 \\
$40-49$ & 8 & 11 & 19 \\
$50-59$ & 0 & 8 & 8 \\
$60-$ & 3 & 8 & 11 \\
Total & 43 & 52 & 95 \\
\hline
\end{tabular}

TABLE 4. Chloride concentration in the sweat of control subjects

\begin{tabular}{|c|c|c|c|c|c|}
\hline \multirow{2}{*}{ Age } & \multirow{2}{*}{$\begin{array}{c}\text { Number of } \\
\text { cases }\end{array}$} & \multicolumn{2}{|c|}{ Sweat weight (g) } & \multicolumn{2}{|c|}{ Sweat $\mathrm{Cl}^{-}$con. (mEq/liter } \\
\hline & & Mean & S.D. & Mean & S.D. \\
\hline $0-9$ & 5 & 0.296 & 0.101 & 13.7 & 3.06 \\
\hline $10-19$ & 9 & 0.354 & 0.133 & 17.3 & 6.05 \\
\hline $20-29$ & 22 & 0.490 & 0.197 & 33.4 & 12.8 \\
\hline $30-39$ & 21 & 0.486 & 0.180 & 29.3 & 12.8 \\
\hline $40-49$ & 19 & 0.304 & 0.155 & 30.4 & 12.6 \\
\hline $50-59$ & 8 & 0.291 & 0.118 & 31.0 & 16.5 \\
\hline $60^{-}$ & 11 & 0.274 & 0.149 & 23.3 & 9.19 \\
\hline Total & 95 & 0.387 & 0.189 & 28.0 & 13.3 \\
\hline
\end{tabular}

The sweat chloride concentration in control subjects

The ages and sexes of the 95 controls are shown in Table 3 . The mean values of sweat chloride concentration in each age group were as follows: $13.7 \mathrm{mEq} /$ liter in the first decade, $17.3 \mathrm{mEq} / \mathrm{liter}$ in the second decade, $33.4 \mathrm{mEq} / \mathrm{liter}$ in the third decade, and about $30 \mathrm{mEq} /$ liter from the third decade on (Table 4). The coefficiency rate in each age group is about $40 \%$. Therefore, the mean value and the mean value $\pm 2 \times$ S.D. of the sweat chloride concentration in the 81 healthy adults from 20 years old were $30 \mathrm{mEq} /$ liter and $4-56 \mathrm{mEq} /$ liter, respectivly. The relationship between the sweat chloride concentration and age in all controls is shown in Fig. 2.

The sweat chloride concentration of patients with various diseases

\section{Chronic pancreatitis}

The concentration in 43 patients with chronic pancreatitis (38 men and 5 women) ranged from $21.7 \mathrm{mEq} /$ liter to $127.0 \mathrm{mEq} /$ iter with a mean value of 58.1 $\mathrm{mEq} /$ liter. In 38 cases of chronic calcifying pancreatitis the mean value was 60.0 $\mathrm{mEq} / \mathrm{liter}$ and this value was significantly higher than that of $30.0 \mathrm{mEq} / \mathrm{liter}$ in the 81 control subjects in the same age groups $(p<0.001)$ (Fig. 3).

If the chronic pancreatitis was divided into two groups by the presence or absence of calcification, the mean value with calcification, $60.0 \mathrm{mEq} / \mathrm{liter}$, was higher than that without calcification, $43.9 \mathrm{mEq} / \mathrm{liter}$, but the difference was not significant (Fig. 4). If the 38 cases of chronic calcifying pancreatitis were grouped 


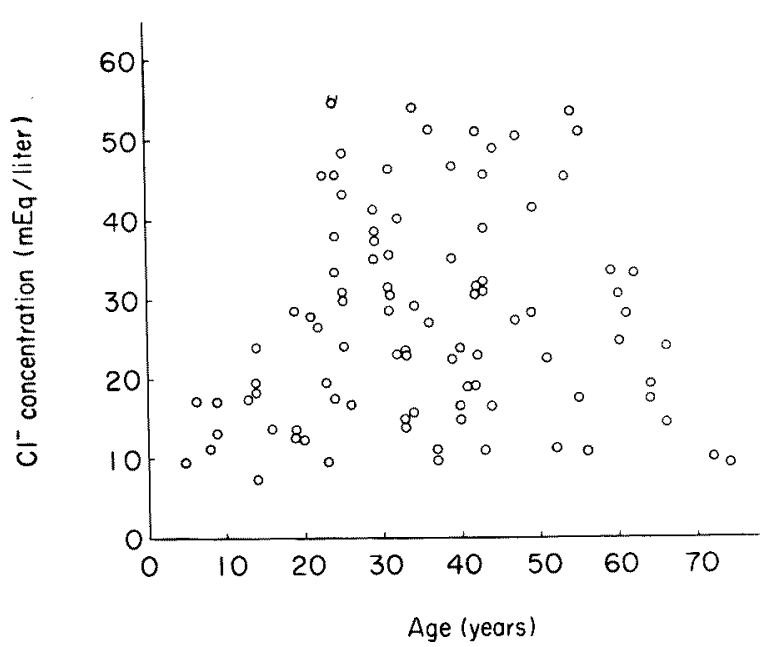

Fig. 2. Age distribution and chloride concentration in the sweat of control subjects $(n=95)$.
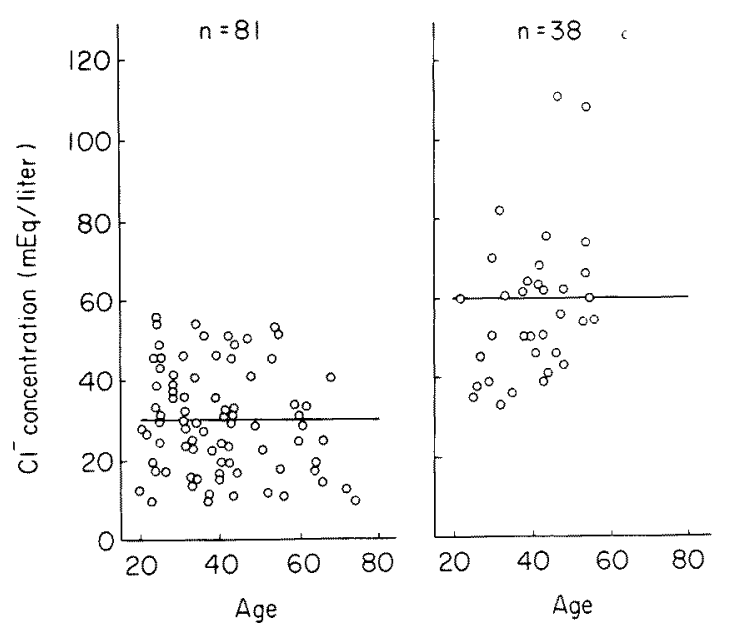

Fig. 3. Chloride concentration in the sweat of control (left) and chronic calcifying pancreatitis (right). Examined at the age 20-79 in both groups.

according to the scale of calcification (Takebe et al. 1972), 22 cases belonged to the small type, 10 cases to the large type and 6 cases to the mixed type. The mean values of the concentration in these three groups were $62.1,63.0$ and $47.4 \mathrm{mEq} /$ liter, respectively, with no significant differences (Fig. 4).

If the 41 cases who habitually drank alcohol were divided into two groups according to whether or not they had drunk $100 \mathrm{~g}$ alcohol a day for 10 years, the mean concentrations of the 23 alcoholic pancreatitis and the 18 non-alcoholic pancreatitis were $58.3 \mathrm{mEq} /$ liter and $56.3 \mathrm{mEq} /$ liter, respectively (Fig. 5). 

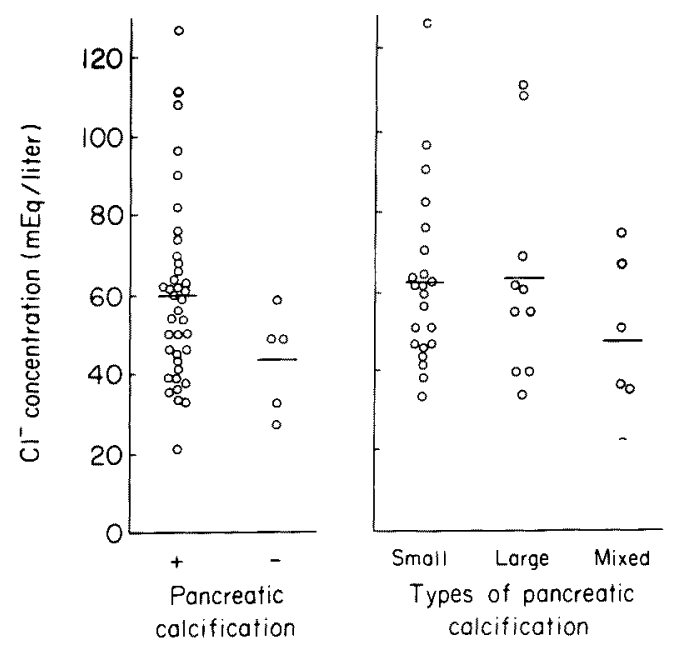

Fig. 4. Chloride concentration in the sweat of patients with chronic pancreatitis.
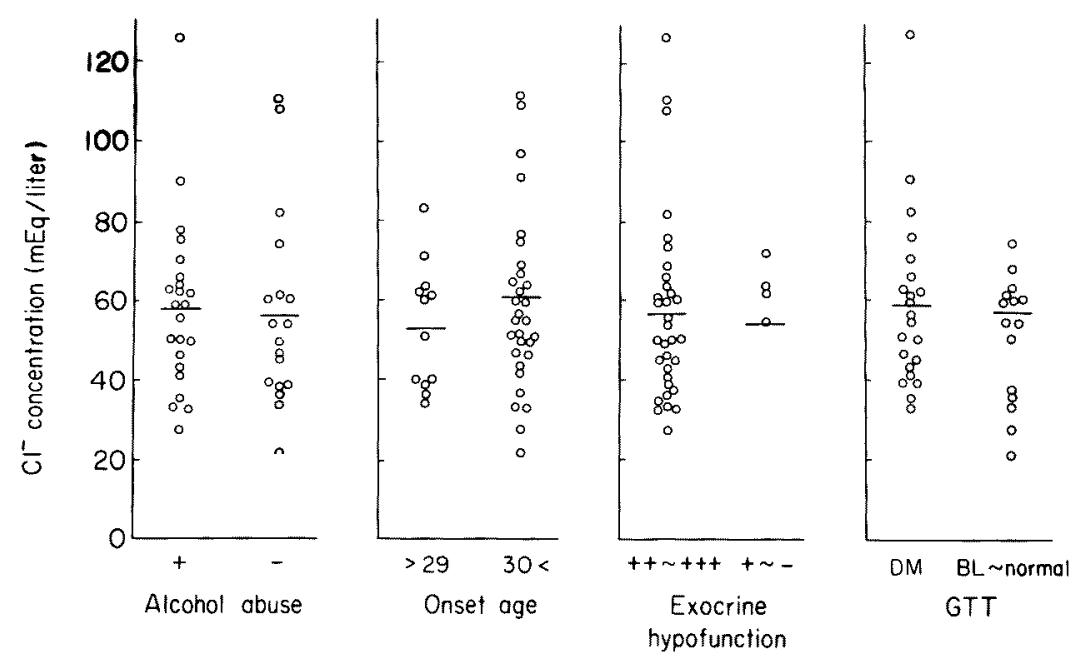

Fig. 5. Chloride concentration in the sweat of patients with chronic panoreatitis.

The sexes and the onset ages of chronic pancretitis are shown in Table 5 . Dividing the subjects into two groups, the one under 30 and the other from 30 years of age, the mean value of the concentration of the former was $52.3 \mathrm{mEq} /$ liter and the latter one was $60.4 \mathrm{mEq} /$ liter, with no significance between the mean values (Fig.5).

If the 38 cases who were tested for CCK-PZ secretin were divided into two groups, the 33 cases which had two or more lesions in the exocrine pancreatic function had a mean concentration of $57.1 \mathrm{mEq} / \mathrm{liter}$ and the 5 cases which had one or no such lesion had a mean concentration of $54.4 \mathrm{mEq} /$ liter (Fig. 5). 
TABLE 5. Onset age of chronic pancreatitis

\begin{tabular}{|c|c|c|c|c|c|c|c|c|c|}
\hline \multirow{2}{*}{ Sex } & \multicolumn{9}{|c|}{ Age } \\
\hline & -19 & $20-29$ & $30-39$ & $40-49$ & $50-59$ & $60-69$ & $70-$ & Mean & Total \\
\hline Male & 0 & 8 & 16 & 12 & 0 & 1 & 1 & 36.8 & 38 \\
\hline Female & 1 & 3 & 0 & 1 & 0 & 0 & 0 & 25.8 & 5 \\
\hline Total & $1(2)$ & $11(26)$ & $16(37)$ & $13(31)$ & $0(0)$ & $1(2)$ & $1(2)$ & 35.5 & $43(100)$ \\
\hline
\end{tabular}

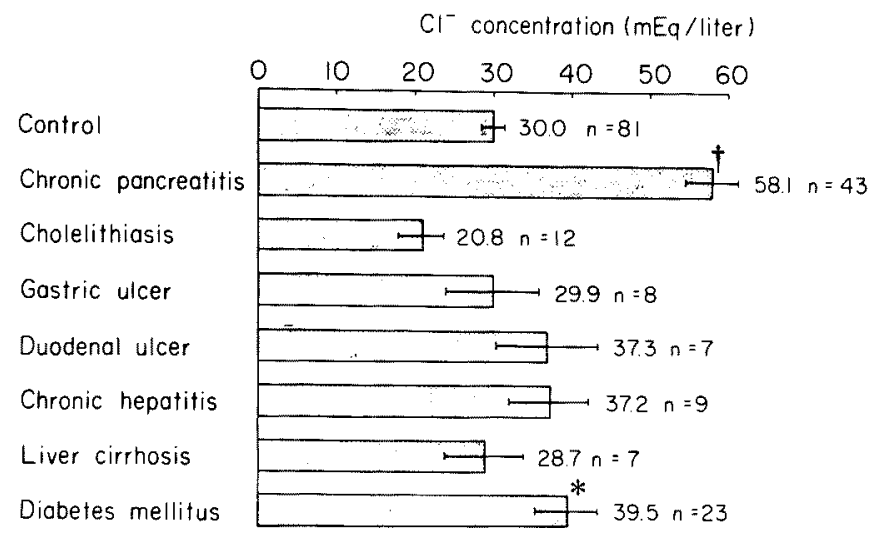

Fig. 6. Chloride concentration in the sweat of control and patients with various diseases. Mean \pm s.D. ${ }^{*} p<0.01 ; \dagger p<0.001$.

If the 39 cases who were given a glucose tolerance test were divided into two groups, the 22 cases of diabetes mellitus and the 17 borderline and normal cases had mean concentration values of $58.7 \mathrm{mEq} /$ liter and $56.9 \mathrm{mEq} / \mathrm{liter}$, respectively; i.e., almost identical values (Fig. 5).

\section{Cholelithiasis}

The sweat chloride concentration of 12 cases ( 7 men and 5 women), consisting of 11 cases of gall stone and 1 choledocholithiasis was $11.8 \mathrm{mEq} / \mathrm{liter}$ to $42.6 \mathrm{mEq} /$ liter and the mean value was $20.8 \mathrm{mEq} /$ liter. There was no significant difference between this mean value and the mean value of the adult controls (Fig. 6).

\section{Peptic ulcer}

The mean value of the sweat chloride concentration of 8 cases $(6$ men and 2 women) of gastric ulcers was $29.9 \mathrm{mEq} /$ liter and that of 7 cases (6 men and woman) of duodenal ulcers was $37.3 \mathrm{mEq} / \mathrm{liter}$. There were no significant differences between these mean values and the mean values of adult controls (Fig. $6)$.

\section{Hepatic diseases}

As hepatic diseases, chronic hepatitis and liver cirrhosis were selected; all 
TABLE 6. Sweat weight of control and patients with various diseases

\begin{tabular}{lccc}
\multicolumn{1}{c}{ Diseases } & Number of cases & \multicolumn{2}{c}{ Sweat weight $(\mathrm{g})$} \\
\hline Control & & Mean & S.D. \\
Chronic pancreatitis & 41 & 0.396 & 0.197 \\
Cholelithiasis & 12 & 0.425 & 0.194 \\
Gastric ulcer & 8 & 0.440 & 0.187 \\
Duodenal ulcer & 7 & 0.400 & 0.109 \\
Chronic hepatitis & 9 & 0.452 & 0.137 \\
Liver cirrhosis & 7 & 0.414 & 0.110 \\
Diabetes mellitus & 23 & 0.424 & 0.212 \\
& & 0.425 & 0.187 \\
\hline
\end{tabular}

cases were histologically diagnosed. The 9 cases of chronic hepatitis ( 7 men and 2 women) had a mean concentration value of $37.2 \mathrm{mEq} /$ liter. The 7 cases of liver cirrhosis ( 5 men and 2 women) had a mean value of $28.7 \mathrm{mEq} / \mathrm{liter}$. Each mean value showed no significant difference in comparison with that of adult controls (Fig. 6).

\section{Diabetes mellitus}

The 23 cases of primary diabetes mellitus ( 8 men and 15 women) had concentrations of $10.2 \mathrm{mEq} /$ liter to $83.3 \mathrm{mEq} /$ liter; the mean value was $39.5 \mathrm{mEq} /$ liter. This was significantly higher than that of the controls $(p<0.01)$ (Fig. 6), but the values showed no relation with the severity of illness judged from GTT.

The mean sweat volumes in these various diseases are tabulated in Table 6; there are no sigfinicant differences between any two groups.

\section{Discussion}

There are two chief methods for collecting the sweat secreted by stimulated sweat glands, that is, thermal sweating and pharmacological sweating. The latter, especially the method of pilocarpine iontophoresis, is esteemed as the more standardized method (Vink 1962). We tried to inject $1.0 \%$ pilocarpine solution into the epidermis, but it proved impossible owing to excessive pain. The method of iontophoresis, on the other hand, is a practical one since the patients experience no pain and even children can be examined if a suitable electric current and the time are selected. The suitable current is $1 \mathrm{~mA}$ because of the risk of burn if the current is over $2 \mathrm{~mA}$. Even if the concentration of pilocarpine solution was changed from $0.1 \%$ to $1.0 \%$, there were no significant differences in the sweat volume and the sweat chloride concentration. But when $1.0 \%$ concentration of pilocarpine solution was used, it was difficult for the sweat to be absorbed by one piece of gauze. A concentration of $0.1 \%$ pilocarpine solution is sufficient for this test. The sweat chloride concentration was changed about $10 \%$ by eating. Therefore the sweat test should be performed in the early morning when hungry.

In healthy controls, it is known that the sweat chloride concentration is 
TABLE 7. Etiological factors in chronic pancreatitis

\begin{tabular}{|c|c|c|c|}
\hline Etiological factors & $\begin{array}{c}\text { Male } \\
(\%)\end{array}$ & $\begin{array}{c}\text { Female } \\
(\%)\end{array}$ & $\begin{array}{c}\text { Total } \\
(\%)\end{array}$ \\
\hline Alcohol* & 47 & 0 & 42 \\
\hline Alcohol+acute pancreatitis & 11 & 0 & 9 \\
\hline Alcohol + cholelithiasis & 3 & 0 & 2 \\
\hline Acute pancreatitis & 0 & 20 & 2 \\
\hline Cholelithiasis & 0 & 20 & 2 \\
\hline Peptic ulcer & 18 & 0 & 16 \\
\hline Others† Hepatitis & 8 & 0 & 7 \\
\hline Familial & 0 & 20 & 2 \\
\hline Unknown & 32 & 40 & 33 \\
\hline Number of cases & 38 & 5 & 43 \\
\hline
\end{tabular}

inclined to rise from childhood to adultfood, but not influenced by age after the age of 20 . Therefore, in adults, the upper limit of the sweat chloride concentration, calculated as the mean value $+2 \times$ s.D., was $60 \mathrm{mEq} / \mathrm{liter}$.

The etiological findings of the 43 cases of chronic pancreatitis are tabulated in Table 7. Cases related solely to alcohol consumption or to alcohol consumption and other etiologies were all males. They comprised $53 \%$ of the total cases, and the cases due to unknown external factors comprised 33\% (32\% in males and $40 \%$ in females). Concerning the onset age, of the total number of cases of young people under 30 years $21 \%$ were male and $80 \%$ were female, leading us to believe that the outbreak of pancreatic disorders in these cases were especially related to congenital factors.

Cystic fibrosis is a congenital disease and it affects primarily the exocrine glands. Among other phenomena, elevation of sweat sodium and chloride concentrations is present from birth and continues throughout life. Protein plugs in pancreatic ducts, which are observed in chronic pancreatitis, characteristically appear in cystic fibrosis, so it is thought that cystic fibrosis, especially the incomplete and adult types, is related to chronic pancreatitis. According to Sarles et al. (1965), the mean value of sweat chloride concentration in 34 cases of chronic calcifying pancreatitis and in 34 controls were $58 \mathrm{mEq} /$ liter and $39 \mathrm{mEq} /$ liter, respectively; the difference being significant.

Although the outbreak frequency of cystic fibrosis is very low in our country, it is interesting that, as in cystic fibrosis, a tendency toward elevated sweat chloride concentrations was observed in chronic pancreatitis. And this phenomenon was found regardless of alcohol consumption, regardless of severe disorders in exocrine pancreatic function, and regardless of the complications of diabetes mellitus. It is therefore possible to consider that it had already existed at the beginning of or prior to the development of chronic pancreatitis. However, since a significant difference in sweat chloride concentrations is not found between young patients (under 30 years old), whose pancreatitis is thought to be related to 
congenital factors, and older patients (from 30 years old), it is difficult to discuss in general causal relation between chronic pancreatitis and elevated sweat electrolytes. A significant difference in sweat volume between controls and cases of chronic pancreatitis was not found, so the difference in sweat chloride concentration did not come from a difference in sweat volume (Table 6).

If cases of chronic calcifying pancreatitis are grouped according to the scale of calcification, alcoholic cases are inclined to belong to the small type and nonalcoholic cases to the large type. Therefore, the scale of calcification is not related to the sweat chloride concentration, which is inclined to rise, regardless of alcohol consumption.

On the other hand, protein plugs in the pancreatic duct are thought to be a starting point for the formation of pancreatic clacification, so it is supposed that elevation of the sweat chloride concentration in chronic pancreatitis, especially in chronic calcifying pancreatitis, is related to the formation of calcification in the pancreatic duct. We have investigated the relationship between the existence of protein plugs in the pancreatic duct and the sweat chloride concentration by observing the tissue of 17 cases of chronic pancreatitis (13 cases with calcification and 4 without clacification). The mean value of sweat chloride concentration of 9 cases with protein plugs in the pancreatic ducts was found to be $78.3 \mathrm{mEq} /$ liter. In contrast, that of 8 cases without protein plugs was significantly lower at $40.5 \mathrm{mEq}$ / liter $(p<0.001)$. Nevertheless, cystic fibrosis is less inclined than chronic pancreatitis to the formation of calcifications, so the mechanisms of formation of the protein plug in the pancreatic duct must differ in the two, despite the fact that both diseases have something in common with regard to abnormal secretion of the sweat glands.

Abnormal elevation of the sweat electrolyte was not found in the various diseases tested, especially in the upper abdominal diseases which are considered to be related to chronic pancreatitis, but a slight elevation of sweat chloride concentration was found in primary diabetes mellitus. Yet, this inclination was more remarkable in chronic pancreatitis than in diabetes melltius; a significant difference $(p<0.01)$ was found between the mean values of sweat chloride concentration. In the 23 cases of primary diabetes mellitus, no complication of notable disturbance in renal function was found. As tests of exocrine pancreatic function were not performed except in one normal case, we cannot deny the possibility that cases of pancreatic diabetes mellitus were included. And it is now difficult to explain the abnormality of sweat chloride concentration in primary diabetes mellitus.

According to these results, it is apparent that cases which have an abnormal secretion of sweat glands similar to cystic fibrosis are included. But further investigation is still needed to elucidate whether or not this phenomenon is a congenital disposition connected with the outbreak of pancreatitis and whether or not it can be used as an index for forecasting the formation of pancreatic calcification. These would include investigations of sweat electrolytes in families with chronic pancreatitis and long-term follow up studies of cases of abnormal levels of 
sweat electrolytes which do not show clinical symptoms or disorders of pancreatic function.

\section{Acknowledğment}

We wish to express our appreciation to Prof. Y. Goto for his advice and criticism in this work.

\section{References}

1) Carey, M.C. \& Fitz Gerald, 0. (1968) Hyperparathyroidism associated with chronic pancreatitis in a family. Gut, 9, 700-703.

2) Gibson, L.E. \& Cooke, R.E. (1959) A test for concentration of electrolytes in sweat in cystic fibrosis of the pancreas utilizing pilocarpine by iontophoresis. Pediatrics, 23, $545-549$.

3) Gross, J.B., Ulrich, J.A. \& Maher, F.T. (1962) Further observations on the hereditary form of pancreatitis. In: Ciba Symposium on the Exocrine Pancreas, edited by A.V.S. de Reuck \& M.P. Cameron, Churchill, London, pp. 278-309.

4) Klatskin, G. \& Gordon, M. (1952) Relationship between relapsing pancreatitis and essential hyperlipemia. Amer. J. Med., 12, 3-23.

5) Koch, E. (1964) Mukoviszidosis und verkalkende Pankreopathie. In: Pathogenese, Diagnostik, Klinik und Therapie der Erkrankungen des exokrinen Pankreas, edited by K. Heinkel \& H. Schön, F.K. Schattauer-Verlag, Stuttgart, pp. 261-270.

6) Novis, M.H., Young, G.O., Bank, S. \& Marks, I.N. (1975) Chronic pancreatitis and alpha-1-antitrypsin. Lancet, 1, 748-749.

7) Paul, A. di Sant' Agnese \& Pamela, B. Davis (1976a) Reseach in cystic fibrosis (First of three parts). New Engl. J. Med., 295, 481-485.

8) Paul, A. di Sant' Agnese \& Pamela, B. Davis (1976b) Reseach in cystic fibrosis (Second of three parts). New Engl. J. Med., 295, 534-541.

9) Paul, A. di Sant' Agnese \& Pamela, B. Davis (1976c) Reseach in cystic fibrosis (Third of three parts). New Engl. J. Med., 295, 597-602.

10) Sarles, H., Muratore, R., Sarles, J.C., Gaini, M., Camette, R., Pastor, J. \& Guien, C. (1965) Aetiology and pathology of chronic pancreatitis. Bibl. gastroent. (Basel), 7, 75-120.

11) Takebe, T., Koizumi, H., Koizumi, K., Sato, T., Fukuda, K., Ishizuki, S., \& Hanawa, M. (1972) Chronic calcifying pancreatitis. Saishin-igaku, 27, 1757-1763. (Japanese)

12) Vink, C.L.J. (1962) Diagnostic value of the sweat test in cystic fibrosis. In: Ciba Symposium on the Exocrine Pancreas, edited by A.V.S. de Reuck \& M.P. Cameron, Churchill, London, pp. 310-328. 